\title{
Are systematic drain tip or drainage fluid cultures predictive of surgical site infections?
}

\author{
H. Macaigne ${ }^{\text {a }}$, V. G. Ruggieri ${ }^{\text {b,c }}$, L.Vallet-Tadeusz ${ }^{\text {a }}$, V. Vernet-Garnier ${ }^{\text {c,d }}$, L.S. Aho-Glélée ${ }^{\mathrm{e}}$, \\ O. Bajolet ${ }^{\mathrm{a}, \mathrm{c}}$, A. Lefebvre ${ }^{\mathrm{a}}$.
}

a. Equipe opérationnelle d'hygiène, CHU Reims, Reims, France

b. Service de chirurgie cardio-thoracique, CHU Reims, Reims, France

c. Structure Fédérative de Recherche CAP-Santé, UFR Médecine, Université de Reims

Champagne-Ardenne, Reims, France

d. Laboratoire de Bactériologie-Virologie-Hygiène, CHU Reims, Reims, France

e. Service d'épidémiologie et d'hygiène hospitalières, CHU de Dijon, Dijon, France

Corresponding author:

Dr Annick Lefebvre

CHU de Reims

Equipe opérationnelle d'hygiène

45 rue Cognacq Jay

51092 Reims cedex.

Phone: +0033310736244.

Fax: 0033326788566.

Email: alefebvre@chu-reims.fr

Short title: Can systematic drainage cultures predict SSI?

Declarations of interest: none 
Word count: 1760.

\section{Abbreviations}

\section{CI: Confidence interval}

NPV: Negative predictive value

OR: Odds ratio

PPV: Predictive positive value

SSI: Surgical site infections 


\begin{abstract}
Background: Systematic cultures of drain tips or drainage fluids for the early detection of surgical site infections (SSI) are controversial.
\end{abstract}

Aim: To examine the association between the results of systematic drain tip or drainage fluid cultures and the occurrence of SSI in clean or clean-contaminated surgery.

Methods: We searched in the Pubmed, and Cat.inist databases for observational studies published before March $31^{\text {st }} 2017$. We included studies reporting results of drain tip or drainage fluid systematic cultures and SSI after clean or clean-contaminated surgeries, and we performed meta-analyses.

Findings: Seventeen studies, including 4,390 patients for drain tip cultures and 1,288 for drainage fluid cultures, were selected. The pooled negative predictive values were high (99\%, 95\% CI [98-100] for drain tip cultures and 98\%, 95\% CI [94-100] for drainage fluid cultures). The positive predictive values were low $(11 \%, 95 \%$ CI [2-24] for drain tip cultures and 12\%, 95\% CI [3-24] for drainage fluid cultures). The sensitivities were low (41\%, 95\% CI [12-73] for drain tip cultures and 37\%, 95\% CI [16-60] for drainage fluid cultures). The specificities were high $(93 \%, 95 \%$ CI [88-96]) for drain tip cultures and moderate (77\%, 95\% CI [54-94]) for drainage fluid cultures.

Conclusion: Systematic cultures of drain tips or drainage fluids appear not to be relevant, because their positive predictive values were low in the prediction of SSI.

\title{
Keywords:
}

Drain tip, drainage fluid, culture, prediction, surgical site infection. 


\section{INTRODUCTION}

Surgical site infections (SSI) are still major surgical complications [1]. The contamination of the surgical site may occur during pre-operative, per-operative or post-operative periods. Surgical drainage can be used to prevent hematoma formation, and thus SSI, but can also be a risk factor for SSI [2]. Indeed, many studies have found an association between the presence of surgical drainage and SSI or between the drainage duration and the proportion of SSI [2-4]. Systematic cultures of drain tips or drainage fluids are commonly used by surgical teams for the early detection of SSI, even in the absence of clinical suspicion of infection. However, their prognostic values are controversial, and the collection and laboratory processing of these samples are costly and time-consuming [5].

We conducted meta-analyses of published comparative studies reporting on the association between results of systematic drain tip or drainage fluid cultures and the occurrence of SSI in clean or clean-contaminated surgery.

\section{METHODS}

The study was performed according to the recommendations of the Preferred Reporting Items for a Systematic Review and Meta-analysis of Diagnostic Test Accuracy Studies (PRISMADTA) [6].

We searched in the Pubmed, and Cat.inist databases for articles published before March 2017. First, we identified three MeSH (Medical Subject Headings) descriptors (1. Surgical wound infection; 2. Drainage; 3. Microbiological techniques) and linked the MeSH terms that corresponded to the descriptors by "OR" and each descriptor was associated by "AND" (Supplemental material 1). A second Pubmed search was performed using the following strategy: “(surgical OR surgery) AND drain[title/abstract] AND culture AND infection[title/abstract]". The Cat.inist base was searched with the equation "suction AND 
drain AND culture AND infection." Finally, a manual search from the bibliography of the selected articles was carried out.

\section{Selection}

Original articles about the use of systematic surgical drain tip or drainage fluid cultures to predict SSI were selected. We excluded studies in which cultures were performed only in cases of suspicion of SSI, as well as studies that only included contaminated or dirty/infected surgeries.

We also contacted five authors of studies that were potentially eligible for inclusion in the meta-analysis in order to obtain additional information or new results [7-11]. Two of them replied to us [7-8].

\section{Quality}

Two readers independently assessed the study limitations for each selected article employing the Newcastle-Ottawa Scale adapted to the specific design of the study [12]. Disagreements between the two reviewers were resolved by consensus.

\section{Meta-analyses}

Data about SSI and drain tip or drainage fluid cultures were extracted from the selected studies and analysed with Stata 11 [13] (metan add-on [14]). Positive predictive values (PPVs), negative predictive values (NPVs), sensitivities and specificities and their respective confidence intervals (CIs) were calculated to evaluate the performance of drain tip cultures and drainage fluids cultures to predict SSI. Odds ratios (ORs) were also calculated. Metaanalyses were also performed studying the concordance between microorganisms isolated in the drain tip or drainage fluid cultures and those isolated in SSI. We used double arcsine 
transformations to stabilize the variance of proportions [15] and a random effect model according to DerSimonian-Laird's method [16]. Heterogeneity was tested by the $\mathrm{I}^{2}$ and Chi2 heterogeneity tests and was explored by subgroup analyses depending on the type of specialty. A potential publication bias was examined by means of funnel plots. We performed two sensitivity analyses. The first set of analyses included studies wherein data were available only in abstract form, but not in full-text form [10-11]. The second set included studies wherein data were available in full-text form, with a score of five or more.

\section{RESULTS}

One hundred and ninety studies were identified. The manual search revealed six new articles. The flow-chart is presented in Figure 1. Seventeen studies were selected (Tables I and II) $[5,7,8,17-30]$.

Twelve studies were prospective and fourteen studies focused on orthopaedic surgery. Drain tip cultures were analysed in eleven articles, drainage fluids were analysed in three articles, and both were analysed in three other articles.

A total of 4,390 patients were included in drain tip culture studies and 1,288 were included in drainage fluid culture studies.

The studies' quality was moderate (Table III).

Between studies, the SSI proportion varied from 0\% (95\% CI [0-11]) to 20\% (95\% CI [10$34])$, and the pooled proportions were $2 \%$ (95\% CI [1-4]) for drain tip culture studies and 5\% (95\% CI [1-10] for drainage fluid culture studies) (Figure 2).

Figure 3 shows the results of PPV for each study. The pooled PPVs were low $(11 \%, 95 \%$ CI [2-24] for drain tip cultures and 12\%, 95\% CI [3-24] for drainage fluid cultures).

Figure 4 shows the results of NPV for each study. The pooled NPVs were high $(99 \%, 95 \%$ CI [98-100] for drain tip cultures and 98\%, 95\% CI [94-100] for drainage fluid cultures). 
The sensitivities were low $\left(41 \%, 95 \%\right.$ CI $[12-73]\left(\mathrm{I}^{2}=88.3 \%, \mathrm{p}<0.001\right)$ for drain tip cultures and $37 \%, 95 \%$ CI $[16-60]\left(\mathrm{I}^{2}=40.1 \%, \mathrm{p}=0.154\right)$ for drainage fluid cultures $)$.

The specificities were high $\left(93 \%, 95 \%\right.$ CI $\left.[88-96]\left(I^{2}=95.4 \%, \mathrm{p}<0.001\right)\right)$ for drain tip cultures and moderate $\left(77 \%, 95 \%\right.$ CI $\left.[54-94]\left(\mathrm{I}^{2}=97.9 \%, \mathrm{p}<0.001\right)\right)$ for drainage fluid cultures.

The ORs showed an association between positive cultures and SSI, which was significant for drain tip cultures $(\mathrm{OR}=11.88,95 \%$ CI [3.38-41.72]) but not for drainage fluid cultures $(\mathrm{OR}=3.42,95 \% \mathrm{CI}[0.70-16.63])$. Subgroup analyses by specialty were performed in the presence of heterogeneity. Only the orthopedic surgery specialty saw more than two studies included. In the subgroup analysis including orthopedic studies only, heterogeneity was still high $\left(\mathrm{I}^{2}=76.6 \%, \mathrm{p}<0.001\right)$.

When studying the concordance between the drain tip or drainage fluid cultures and the SSI isolated bacteria, PPVs were very low $(6 \%, 95 \%$ CI [0-23] for drain tip cultures and 7\%, 95\% CI [1-18] for drainage fluid cultures) (Supplemental material 2).

The funnel plot (Figure 5) did not suggest a publication bias.

Sensitivity analyses gave similar results (Supplemental material 3).

\section{DISCUSSION}

This study allowed us to determine the performances of systematic drain tip or drainage fluid cultures in the prediction of SSI and in the prediction of the microorganisms involved in SSI. Systematic drain tip or drainage fluid cultures seem to be of little value since the PPVs that represent the probability of SSI in the presence of a positive culture were low $(11 \%, 95 \% \mathrm{CI}$ [2-24] for drain tip cultures and 12\%, 95\% CI [3-24] for drainage fluid cultures). Moreover, the micro-organisms identified in the cultures did not systematically correspond to the microorganisms involved in SSI (PPVs of 6\%, 95\% CI [0-23] for drain tip cultures and 7\%, 95\% CI [1-18] for drainage fluid cultures). Sensitivities were also poor; thus systematic drain tip or 
drainage fluid cultures are not reliable predictors of SSI in the absence of clinical signs. Therefore, due to the lack of benefit, the associated costs $(24,30$ euros for a drain tip or a drainage fluid culture in France) and the risk of unnecessary or inappropriate antibiotic treatment, use of these cultures has been discouraged in our facility. The microbiology examination that should be performed is culture of biopsies, or material collected during revision surgery [31].

The low relevance of systematic drain tip or drainage fluid cultures has been shown in several studies, particularly dealing with orthopedic surgery $[25,26,29,30]$.

However, in the study conducted by Bernard et al. [20], drainage fluid cultures seemed to be promising in septic surgery with a PPV of $87 \%$, being particularly useful in the follow-up of the efficacy of surgical and antibiotic treatments.

The NPVs were high in our meta-analysis (99\%, 95\% CI [98-100] for drain tip cultures and $98 \%, 95 \%$ CI [94-100] for drainage fluid cultures). However, the added value of this test is poor as the incidence of SSI is low in the literature (from $0.6 \%$ in knee prosthesis surgery to $10.7 \%$ non-endoscopic colorectal surgery) [32] and in studies included in our meta-analysis. The heterogeneity was high $(>50 \%$ and $\mathrm{p}<0.001)$. This heterogeneity was not explained by the type of surgical specialty, but might be explained by the differences in sampling methods or microbiological techniques. The sampling methods varied significantly between studies and were not sufficiently described in several studies. It was therefore not possible to take them into account in our meta-analysis.

To our knowledge, this is the first meta-analysis to explore the performances of systematic drain tip or drainage fluid cultures after clean or clean-contaminated surgery in the prediction of SSI. We included 17 studies involving 4,390 patients for drain tip cultures and 1,288 patients for drainage fluid cultures. Although an association between positive cultures and SSI was observed in several included studies, several of them did not show the performances in 
terms of NPV, PPV, sensitivity and specificity of these cultures [17,21,24,29]. Our metaanalysis allowed us to determine these performances in the prediction of SSI and to pool them.

The Newcastle-Ottawa scale was preferred to the QUADAS-2 [33] scale usually used for the assessment of diagnostic accuracy studies as the Newcastle-Ottawa scale allowed us to evaluate more items. Only the evaluation of the presence of SSI without knowledge of the culture was not assessed, but this information was never mentioned in selected studies $[5,7,8,17-30]$.

This meta-analysis also has limitations, in particular the inclusion of studies with a medium quality and/or methods poorly described and retrospective studies. Only three had a score of six or more in the Newcastle-Ottawa quality assessment scale. Moreover, some confidence intervals were wide. Finally, the limited number of studies included, as well as the heterogeneity between studies should lead one to interpret results with caution. Although a high NPV is not interesting in the context of systematic cultures, it could be interesting in cases of clinical suspicion or clinical diagnosis of SSI, or in contaminated or infected surgery. Some studies deal with cultures in this context but were not included in our meta-analyses [34]. Such meta-analyses could be conducted to determine the performance of drain tip or drainage fluid cultures in this context. If the PPV were high, this might allow one to confirm SSI or to adapt the antibiotic treatment. However, only early SSI would be identified since drains are usually removed a few days after surgery.

\section{CONCLUSION}

Our meta-analysis showed that the systematic cultures of drain tips or drainage fluids were of low relevance since the PPV were low in the prediction of SSI. Moreover, the associated costs 
and the risk of useless or inappropriate antibiotic treatment should lead one to discourage the performance of systematic cultures in asymptomatic patients.

It would be interesting to provide meta-analyses that include only studies in which cultures were performed for patients who are experiencing clinical signs or in contaminated or infected surgery. 


\section{ACKNOWLEDGMENTS}

We thank Marjorie Cantener and Fawn Wilderson for their editorial assistance.

Funding: none 


\section{REFERENCES}

[1] Whitehouse JD, Friedman ND, Kirkland KB, Richardson WJ, Sexton DJ. The Impact of Surgical-Site Infections Following Orthopedic Surgery at a Community Hospital and a University Hospital Adverse Quality of Life, Excess Length of Stay, and Extra Cost. Infect Control Hosp Epidemiol 2002;23:183-189. https://doi.org/10.1086/502033.

[2] Reiffel AJ, Barie PS, Spector JA. A Multi-Disciplinary Review of the Potential Association between Closed-Suction Drains and Surgical Site Infection. Surg Infect 2013;14:244-269. https://doi.org/10.1089/sur.2011.126.

[3] Barbadoro P, Marmorale C, Recanatini C, Mazzarini G, Pellegrini I, D’Errico MM, et al. May the drain be a way in for microbes in surgical infections? Am J Infect Control 2016 Mar 1;44:283-288. https://doi.org/10.1016/j.ajic.2015.10.012.

[4] Tschudin-Sutter S, Meinke R, Schuhmacher H, Dangel M, Eckstein F, Reuthebuch O, et al. Drainage days-an independent risk factor for serious sternal wound infections after cardiac surgery: a case control study. Am J Infect Control 2013;41:1264-1267. https://doi.org/10.1016/j.ajic.2013.03.311.

[5] Ahn J-S, Lee H-J, Park E, Park I-Y, Lee JW. Suction Drain Tip Culture after Spine Surgery: Can It Predict a Surgical Site Infection? Asian Spine J 2015;9:863-868. https://doi.org/10.4184/asj.2015.9.6.863.

[6] McInnes MDF, Moher D, Thombs BD, McGrath TA, Bossuyt PM, the PRISMA-DTA Group. Preferred Reporting Items for a Systematic Review and Meta-analysis of Diagnostic Test Accuracy Studies: The PRISMA-DTA Statement. JAMA 2018;319:388-396. https://doi.org/10.1001/jama.2017.19163.

[7] Yamada T, Yoshii T, Egawa S, Takada R, Hirai T, Inose H, et al. Drain tip culture is not prognostic for surgical site infection in spinal surgery under prophylactic use of antibiotics. Spine 2016;41:1179-1184. https://doi.org/10.1097/BRS.0000000000001503 
[8] Lindahl J, Korkala O, Pammo H, Miettinen A. Bacterial contamination and closed suction drainage in open meniscectomy of the knee. Ann Chir Gynaecol 1993;82:51-54.

[9] Anoumou M, Traoré M, Kouamé M, Gogoua R, Ouassa T, Guy V. [Relevance of the systematic culture of the intraoperative swab and drain tip of Redon in orthopaedictraumatology surgery] West Afr J Med. 2007;26:238-42.

[10] Cosseron M, Boisrenoult P, Court C, Gagey O, Nordin JY, Nordmann P. Intérêt des cultures systématiques du liquide de drainage en chirurgie de classe I et II d'Altemeier. Rev Chir Orthop Reparatrice Appar Mot 2002;88:113-116

[11] Lazureanu V, Radu D, Vermesan D, Prejbeanu R, Florescu S, Trocan I, et al. Drain tip cultures do not predict infections in primary total knee arthroplasty. Clin Ter. 2015;166:e153-7. doi: 10.7417/T.2015.1846.

[12] Stang A. Critical evaluation of the Newcastle-Ottawa scale for the assessment of the quality of nonrandomized studies in meta-analyses. Eur J Epidemiol 2010;25:603-605. https://doi.org/10.1007/s10654-010-9491-z

[13] StataCorp LP. Stata/SE 10.0. Stata Corp. College Station, TX, USA. 2007.

[14] Harris R, Bradburn M, Deeks J, Harbord R, Altman D, Sterne J. metan: fixed- and random-effects meta-analysis. Stata Journal 2008;8:3.

[15] Rucker G, Schwarzer G, Carpenter J. Arcsine test for publication bias in meta-analyses with binary outcomes. Stat Med 2008;27:746-763. https://doi.org/10.1002/sim.2971

[16] DerSimonian R, Laird N. Meta-analysis in clinical trials. Control Clin Trials 1986;7:177-188.

[17] Aski B, Vaidya N, Patil R, Pinto N. Drain tip culture following total knee arthroplasty. Int J Res Med Sci 2017;3:409-411. 
[18] Becker GD, Welch WD. Quantitative bacteriology of closed-suction wound drainage in contaminated surgery. Laryngoscope 1990;100:403-406. https://doi.org/10.1288/00005537-199004000-00014

[19] Becker GD. Ineffectiveness of closed suction drainage cultures in the prediction of bacteriologic findings in wound infections in patients undergoing contaminated head and neck cancer surgery. Otolaryngol--Head Neck Surg Off J Am Acad Otolaryngol-Head Neck Surg 1985;93:743-747. https://doi.org/10.1177/019459988509300608

[20] Bernard L, Pron B, Vuagnat A, Gleizes V, Signoret F, Denormandie P, et al. The Value of Suction Drainage Fluid Culture during Aseptic and Septic Orthopedic Surgery: A Prospective Study of 901 Patients. Clin Infect Dis 2002;34:46-49. https://doi.org/10.1086/338045

[21] Degnim AC, Scow JS, Hoskin TL, Miller JP, Loprinzi M, Boughey JC, et al. Randomized controlled trial to reduce bacterial colonization of surgical drains after breast and axillary operations. Ann Surg 2013;258:240-247. https://doi.org/10.1097/SLA.0b013e31828c0b85

[22] Girvent R, Marti D, Munoz JM. The clinical significance of suction drainage cultures. Acta Orthop Belg 1994;60:290.

[23] Gunterberg R, Bergmann B, Brandberg A, Karlsson J. Bacterial growth on drain tips after total hip replacement. A controlled culture method. Eur J Orthop Surg Traumatol 1996;6:105-108. https://doi.org/10.1007/BF00568324

[24] Krishnan J, Harshan KH, Meera Shenoy T. Suction Drain Tip Cultures and Predictors of Surgical Site Infections in Hip Fractures. J Sci Res 2014;3:1955-1959.

[25] Overgaard S, Thomsen NO, Kulinski B, Mossing NB. Closed suction drainage after hip arthroplasty. Prospective study of bacterial contamination in 81 cases. Acta Orthop Scand 1993;64:417-420. 
[26] Petsatodis G, Parziali M, Christodoulou AG, Hatzokos I, Chalidis BE. Prognostic value of suction drain tip culture in determining joint infection in primary and non-infected revision total hip arthroplasty: a prospective comparative study and review of the literature. Arch Orthop Trauma Surg 2009;129:1645-1649. https://doi.org/10.1007/s00402-009-0844-6

[27] Sankar B, Ray P, Rai J. Suction drain tip culture in orthopaedic surgery: a prospective study of 214 clean operations. Int Orthop 2004;28:311-314. https://doi.org/10.1007/s00264-004-0561-2

[28] Takada R, Jinno T, Koga D, Hirao M, Muneta T, Okawa A. Is Drain Tip Culture Prognostic of Surgical Site Infection? Results of 1380 Drain Tip Cultures in Total Hip Arthroplasty. J Arthroplasty 2015;30:1407-1409. https://doi.org/10.1016/j.arth.2015.02.038

[29] Weinrauch P. Diagnostic value of routine drain tip culture in primary joint arthroplasty. ANZ J Surg 2005;75:887-888. https://doi.org/10.1111/j.1445-2197.2005.03546.x

[30] Zamora-Navas P, Collado-Torres F, de la Torre-Solís F. Closed suction drainage after knee arthroplasty. A prospective study of the effectiveness of the operation and of bacterial contamination. Acta Orthop Belg 1999;65:44-47.

[31] Ministère de l'Emploi et de la Solidarité, Secrétariat d'Etat à la Santé et à l'action sociale, Comité technique national des infections nosocomiales. 100 recommandations pour la surveillance et la prévention des infections nosocomiales. http://www.ladocumentationfrancaise.fr/var/storage/rapports-publics/014000029.pdf. Accessed August 13, 2017.

[32] European Centre for Disease Prevention and Control. Annual Epidemiological Report 2016 - Surgical site infections. 
https://www.ecdc.europa.eu/sites/portal/files/documents/AER-HCAI-SSI.pdf. Accessed August 13, 2017.

[33] Whiting PF, Rutjes AW, Westwood ME, Mallett S, Deeks JJ, Reitsma JB, et al. QUADAS-2: a revised tool for the quality assessment of diagnostic accuracy studies. Ann Intern Med. 2011 18;155:529-36. doi: 10.7326/0003-4819-155-8-20111018000009.

[34] Legout L, Stern R, Assal M, Rohner P, Merle C, Hoffmeyer P, et al. Suction drainage culture as a guide to effectively treat musculoskeletal infection. Scand J Infect Dis 2006;38:341-345. https://doi.org/10.1080/00365540500488899

[35] Horan TC, Gaynes RP, Martone WJ, Jarvis WR, Emori TG. CDC definitions of nosocomial surgical site infections, 1992: a modification of CDC definitions of surgical wound infections. Infect Control Hosp Epidemiol 1992;13:606-8.

[36] Mangram AJ, Horan TC, Pearson ML, Silver LC, Jarvis WR. Guideline for prevention of surgical site infection, 1999. Hospital infection control practices advisory committee. Infect Control Hosp Epidemiol 1999;20:250-78. 


\section{Figure legends}

Figure 1. Flow chart for studies selection and inclusion

Figure 2. Meta-analysis of surgical site infections proportion in selected studies

Figure 3. Meta-analysis of positive predictive positive value of drain tip or drainage fluid cultures in the prediction of surgical site infections in selected studies

Figure 4. Meta-analysis of negative predictive value of drain tip or drainage fluid cultures in the prediction of surgical site infections in selected studies.

Figure 5. Funnel plot of selected studies 


\section{Tables}

Table I. Characteristics of the included studies

\begin{tabular}{|c|c|c|c|c|c|c|c|c|c|c|}
\hline Authors & Year & Country & Type of study & Type of surgery & $\begin{array}{l}\text { Type of } \\
\text { sample }\end{array}$ & $\begin{array}{l}\text { Drainage } \\
\text { duration }\end{array}$ & \begin{tabular}{|l|} 
Prophylactic \\
antibiotic \\
treatment \\
duration \\
\end{tabular} & $\begin{array}{l}\text { Duration of } \\
\text { follow-up }\end{array}$ & Inclusion criteria & \begin{tabular}{|l} 
Number \\
of \\
included \\
patients \\
\end{tabular} \\
\hline $\begin{array}{l}\text { Ahn et al. } \\
{[5]}\end{array}$ & 2015 & Corea & Retrospective & Orthopaedic & Drain tip & 4.5 days & 5 days & 1 year & CDC criteria [35] & 133 \\
\hline $\begin{array}{l}\text { Aski et al. } \\
\text { [17] }\end{array}$ & 2015 & India & Prospective & Orthopaedic & Drain tip & $\leq 48$ hours & 3 days & 6 months & Unspecified & 338 \\
\hline $\begin{array}{l}\text { Becker et } \\
\text { al. [18] }\end{array}$ & 1990 & USA & Prospective & $\begin{array}{l}\text { Ear, nose and } \\
\text { throat }\end{array}$ & $\begin{array}{l}\text { Drainage } \\
\text { fluid }\end{array}$ & Unspecified & 3 days & Unspecified & $\begin{array}{l}\text { Presence of pus } \\
\text { postoperatively }\end{array}$ & 41 \\
\hline $\begin{array}{l}\text { Becker et } \\
\text { al. [19] }\end{array}$ & 1985 & USA & Prospective & $\begin{array}{l}\text { Ear, nose and } \\
\text { throat }\end{array}$ & $\begin{array}{l}\text { Drainage } \\
\text { fluid }\end{array}$ & Unspecified & $\begin{array}{l}\text { During } \\
\text { drainage }\end{array}$ & Unspecified & $\begin{array}{l}\text { Presence of pus } \\
\text { postoperatively }\end{array}$ & 30 \\
\hline $\begin{array}{l}\text { Bernard et } \\
\text { al. [20] }\end{array}$ & 2002 & France & Prospective & Orthopaedic & $\begin{array}{l}\text { Drainage } \\
\text { fluid }\end{array}$ & Unspecified & Unspecified & $\begin{array}{l}1 \text { month, } 1 \\
\text { year if } \\
\text { presence of } \\
\text { implant }\end{array}$ & Unspecified & 843 \\
\hline $\begin{array}{l}\text { Degnim et } \\
\text { al. [21] }\end{array}$ & 2013 & USA & Prospective & Breath & $\begin{array}{l}\text { Drainage } \\
\text { fluid and } \\
\text { drain tip }\end{array}$ & $\begin{array}{l}4 \text { to19 days } \\
\text { (mean=7 } \\
\text { days) }\end{array}$ & $\leq 24$ hours & 30 days & $\begin{array}{l}\text { CDC criteria ("purulent } \\
\text { drainage, positive } \\
\text { aseptically collected } \\
\text { culture from the wound, } \\
\text { signs of inflammation with } \\
\text { opening of incision and }\end{array}$ & 100 \\
\hline
\end{tabular}




\begin{tabular}{|c|c|c|c|c|c|c|c|c|c|c|}
\hline Authors & Year & Country & Type of study & Type of surgery & $\begin{array}{l}\text { Type of } \\
\text { sample }\end{array}$ & $\begin{array}{l}\text { Drainage } \\
\text { duration }\end{array}$ & \begin{tabular}{|l|} 
Prophylactic \\
antibiotic \\
treatment \\
duration \\
\end{tabular} & $\begin{array}{l}\text { Duration of } \\
\text { follow-up }\end{array}$ & Inclusion criteria & \begin{tabular}{|l|}
$\begin{array}{l}\text { Number } \\
\text { of } \\
\text { included } \\
\text { patients }\end{array}$ \\
\end{tabular} \\
\hline & & & & & & & & & $\begin{array}{l}\text { absence of a negative } \\
\text { culture, or physician } \\
\text { diagnosis of infection } \\
\text { (which could include } \\
\text { cellulitis)") } \\
\end{array}$ & \\
\hline $\begin{array}{l}\text { Girvent et } \\
\text { al. [22] }\end{array}$ & 1994 & Spain & Prospective & Orthopaedic & Drain tip & $\begin{array}{l}\text { Ablation if } \\
\text { volume }<20 \\
\mathrm{~mL} / \text { days } \\
\text { (untill } 6 \text { days) }\end{array}$ & Variable & Unspecified & $\begin{array}{l}\text { "any clinical signs of } \\
\text { infection of the wound } \\
\text { (redness, swelling, increase } \\
\text { in the local temperature } \\
\text { and exsudation)" }\end{array}$ & 72 \\
\hline $\begin{array}{l}\text { Gunterberg } \\
\text { et al. [23] }\end{array}$ & 1996 & Sweden & Prospective & Orthopaedic & Drain tip & 48 hours & 48 hours & 12 months & $\begin{array}{l}\text { "purulent drainage, serous } \\
\text { discharge } \\
\text { from the wound with the } \\
\text { growth of bacteria at } \\
\text { reoperation" }\end{array}$ & 105 \\
\hline $\begin{array}{l}\text { Krishnan et } \\
\text { al. [24] }\end{array}$ & 2012 & India & Retrospective & Orthopaedic & Drain tip & 48 hours & 3 days & Unspecified & Unspecified & 156 \\
\hline $\begin{array}{l}\text { Lindahl J. } \\
\text { [8] }\end{array}$ & 1993 & Finland & Prospective & Orthopaedic & $\begin{array}{l}\text { Drainage } \\
\text { fluid and } \\
\text { drain tip }\end{array}$ & \begin{tabular}{|l|}
3 groups: 12, \\
24 and 48 \\
hours
\end{tabular} & None & 1 month & Unspecified & 60 \\
\hline $\begin{array}{l}\text { Overgaard } \\
\text { et al. [25] }\end{array}$ & 1993 & Denmark & Prospective & Orthopaedic & Drain tip & \begin{tabular}{|l} 
Ablation if \\
volume $<20$ \\
$\mathrm{~mL}$ during \\
12 hours \\
mean $=1.8$ \\
days
\end{tabular} & $\begin{array}{l}\text { During } \\
\text { drainage }\end{array}$ & 1 year & $\begin{array}{l}\text { "purulent matter in the } \\
\text { wound, or signs of } \\
\text { infection including positive } \\
\text { culture" }\end{array}$ & 81 \\
\hline $\begin{array}{l}\text { Petsatodis } \\
\text { et al. [26] }\end{array}$ & 2009 & Greece & Prospective & Orthopaedic & Drain tip & 48 hours & 48 hours & 2.8 years & Unspecified & 110 \\
\hline
\end{tabular}




\begin{tabular}{|c|c|c|c|c|c|c|c|c|c|c|}
\hline Authors & Year & Country & Type of study & Type of surgery & $\begin{array}{l}\text { Type of } \\
\text { sample }\end{array}$ & $\begin{array}{l}\text { Drainage } \\
\text { duration }\end{array}$ & $\begin{array}{l}\text { Prophylactic } \\
\text { antibiotic } \\
\text { treatment } \\
\text { duration } \\
\end{array}$ & $\begin{array}{l}\text { Duration of } \\
\text { follow-up }\end{array}$ & Inclusion criteria & \begin{tabular}{|l|} 
Number \\
of \\
included \\
patients
\end{tabular} \\
\hline $\begin{array}{l}\text { Sankar et } \\
\text { al. [27] }\end{array}$ & 2004 & India & Prospective & Orthopaedic & $\begin{array}{l}\text { Drainage } \\
\text { fluid and } \\
\text { drain tip }\end{array}$ & $\begin{array}{l}\text { Ablation if } \\
\text { volume }< \\
100 \mathrm{ml} / 24 \\
\text { hours } \\
\text { (24- } 48 \text { hours) }\end{array}$ & 16 hours & 1 year & $\begin{array}{l}\text { "purulent matter in the } \\
\text { wound drained } \\
\text { spontaneously or by } \\
\text { incision, serous discharge } \\
\text { from the wound with } \\
\text { growth of bacteria, or } \\
\text { signs of infection with } \\
\text { growth of bacteria at } \\
\text { reoperation" }\end{array}$ & 214 \\
\hline $\begin{array}{l}\text { Takada et } \\
\text { al. [28] }\end{array}$ & 2015 & Japan & Retrospective & Orthopaedic & Drain tip & 12 to 72 hours & 48 hours & 4.7 years & $\begin{array}{l}\text { "Any possible signs of SSI } \\
\text { such as wound } \\
\text { discharge or dehiscence, } \\
\text { fever, pain, and an } \\
\text { increase of level of C } \\
\text { reactive protein or } \\
\text { erythrocyte sedimentation } \\
\text { rate" }\end{array}$ & 1,380 \\
\hline $\begin{array}{l}\text { Weinrauch } \\
\text { [29] }\end{array}$ & 2005 & Australia & Retrospective & Orthopaedic & Drain tip & 24 hours & $\begin{array}{l}\text { During } \\
\text { drainage }\end{array}$ & $\begin{array}{l}8.9 \text { months } \\
\text { ( } 3 \text { months } \\
\text { minimum) }\end{array}$ & Unspecified & 393 \\
\hline $\begin{array}{l}\text { Yamada et } \\
\text { al. [7] }\end{array}$ & 2016 & Japan & Retrospective & Orthopaedic & Drain tip & 48 hours & 48 hours & $\begin{array}{l}3 \text { years }(0.5- \\
5.5 \text { years })\end{array}$ & $\begin{array}{l}\text { CDC criteria [36] - "the } \\
\text { presence of SSI was } \\
\text { confirmed by reoperation } \\
\text { or by histopathologic } \\
\text { or radiologic investigation" }\end{array}$ & 1,240 \\
\hline $\begin{array}{l}\text { Zamora et } \\
\text { al. [30] }\end{array}$ & 1999 & Spain & Prospective & Orthopaedic & Drain tip & $\begin{array}{l}3 \text { groups: } 12 \\
24 \text { and } 48 \\
\text { hours }\end{array}$ & 2 days & Unspecified & $\begin{array}{l}\text { "The evaluation of the } \\
\text { healing of the wound was } \\
\text { done taking into account } \\
\text { the presence of purulent }\end{array}$ & 32 \\
\hline
\end{tabular}




\begin{tabular}{|l|l|l|l|l|l|l|l|l|l|}
\hline Authors & Year & Country & Type of study & Type of surgery & $\begin{array}{l}\text { Type of } \\
\text { sample }\end{array}$ & $\begin{array}{l}\text { Drainage } \\
\text { duration }\end{array}$ & $\begin{array}{l}\text { Prophylactic } \\
\text { antibiotic } \\
\text { treatment } \\
\text { duration }\end{array}$ & $\begin{array}{l}\text { Duration of } \\
\text { follow-up }\end{array}$ & $\begin{array}{l}\text { Inclusion criteria } \\
\text { of } \\
\text { included } \\
\text { patients }\end{array}$ \\
\hline & & & & & & & $\begin{array}{l}\text { matter coming from the } \\
\text { wound, as well as other } \\
\text { signs of infection or a } \\
\text { positive culture" }\end{array}$ & \\
\hline
\end{tabular}


Table II. Description of microbiologic methods in the included studies

\begin{tabular}{|c|c|c|c|c|c|c|c|c|}
\hline Authors & Year & $\begin{array}{l}\text { Type of } \\
\text { sample }\end{array}$ & $\begin{array}{l}\text { Incubation } \\
\text { time }\end{array}$ & Culture medium & \begin{tabular}{|l} 
Analysis \\
(qualitative or \\
quantitative)
\end{tabular} & $\begin{array}{l}\text { Transport } \\
\text { medium } \\
\text { (yes/no) }\end{array}$ & Sampling mode & \begin{tabular}{|l|} 
Skin \\
disinfection \\
before drain \\
removal \\
\end{tabular} \\
\hline $\begin{array}{l}\text { Becker et } \\
\text { al. }\end{array}$ & 1990 & $\begin{array}{l}\text { Drainage } \\
\text { fluid }\end{array}$ & Unspecified & $\begin{array}{l}\text { Aerobic and Anaerobic blood agar } \\
\text { plate, laked blood agar plate, } \\
\text { Fusobacterium agar plate, phenyl } \\
\text { ethyl alcohol agar plate, chocolate } \\
\text { agar plate, McConkey agar plate }\end{array}$ & Quantitative & Yes & $\begin{array}{l}\text { "on the second or } \\
\text { third postoperative } \\
\text { day, a sample of } \\
\text { wound drainage was } \\
\text { aspirated from the } \\
\text { drain line into a } \\
\text { syringe" }\end{array}$ & Unspecified \\
\hline
\end{tabular}




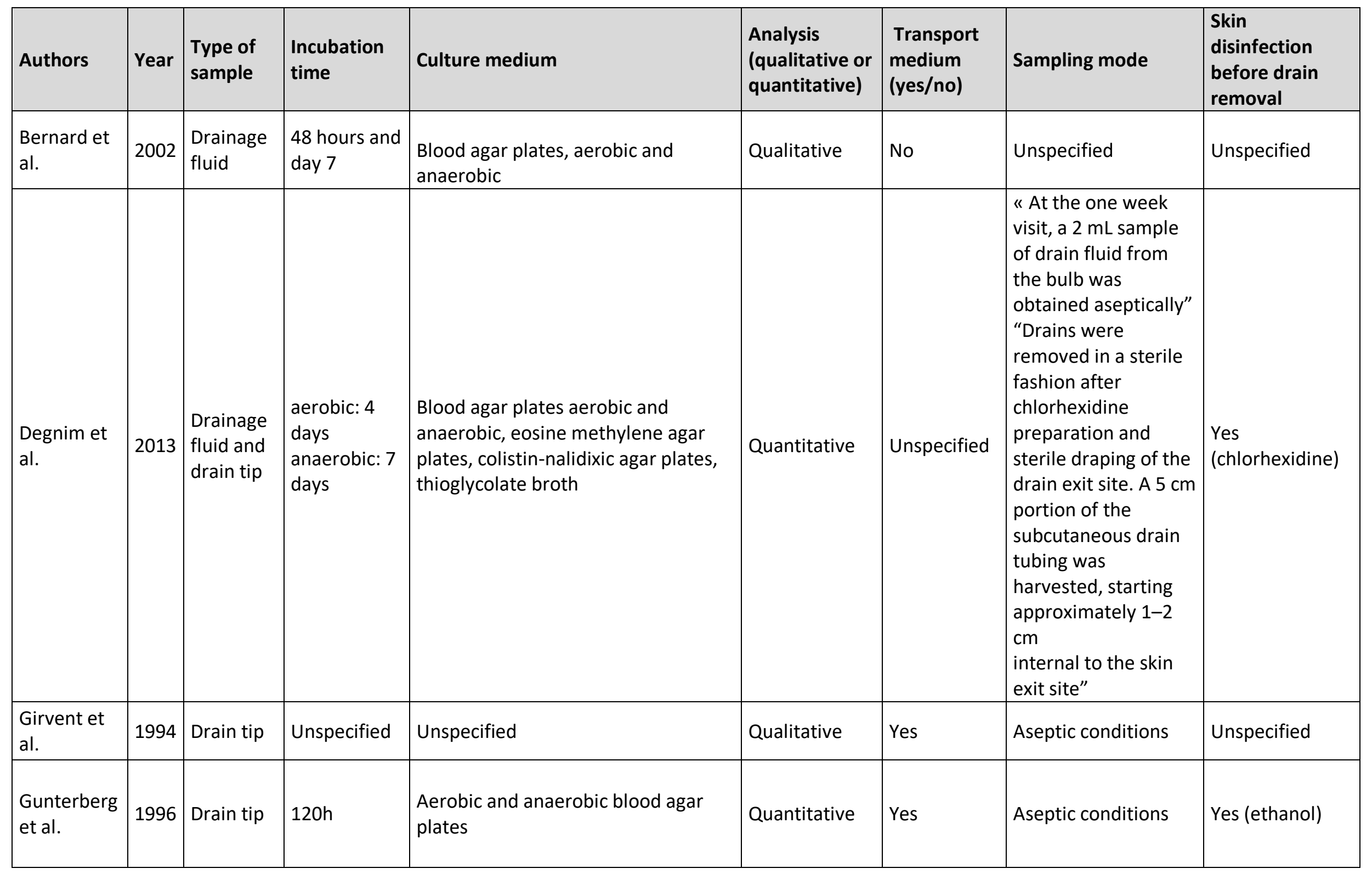




\begin{tabular}{|c|c|c|c|c|c|c|c|c|}
\hline Authors & Year & $\begin{array}{l}\text { Type of } \\
\text { sample }\end{array}$ & $\begin{array}{l}\text { Incubation } \\
\text { time }\end{array}$ & Culture medium & $\begin{array}{l}\text { Analysis } \\
\text { (qualitative or } \\
\text { quantitative) }\end{array}$ & $\begin{array}{l}\text { Transport } \\
\text { medium } \\
\text { (yes/no) }\end{array}$ & Sampling mode & $\begin{array}{l}\text { Skin } \\
\text { disinfection } \\
\text { before drain } \\
\text { removal } \\
\end{array}$ \\
\hline $\begin{array}{l}\text { Krishnan et } \\
\text { al. }\end{array}$ & 2012 & Drain tip & Unspecified & Unspecified & Qualitative & Unspecified & Unspecified & Unspecified \\
\hline Lindahl J. & 1993 & $\begin{array}{l}\text { Drainage } \\
\text { fluid and } \\
\text { drain tip }\end{array}$ & $\begin{array}{l}\text { Unspecified } \\
\text { (méthode } \\
\text { standard) }\end{array}$ & Unspecified (« standard methods ») & Qualitative & Yes & Unspecified & Yes ( $80 \%$ alcool) \\
\hline $\begin{array}{l}\text { Overgaard } \\
\text { et al. }\end{array}$ & 1993 & Drain tip & $48 \mathrm{~h}$ & $0.3 \%$ natrium-thiogluconate & Qualitative & Yes & $\begin{array}{l}\text { "Under sterile } \\
\text { conditions } \\
2 \mathrm{~cm} \text { from the end } \\
\text { tip" }\end{array}$ & Yes \\
\hline $\begin{array}{l}\text { Petsatodis } \\
\text { et al. }\end{array}$ & 2009 & Drain tip & $48-72 h$ & Unspecified & Qualitative & Unspecified & $\begin{array}{l}\text { Aseptic conditions- } \\
\text { "The drain tip } \\
\text { was cut of } \\
\text { approximately 5-10 } \\
\text { cm from its far end } \\
\text { utilising } \\
\text { single-use sterile } \\
\text { scissors. " }\end{array}$ & $\begin{array}{l}\text { Yes (povidone } \\
\text { iodine) }\end{array}$ \\
\hline $\begin{array}{l}\text { Sankar et } \\
\text { al. }\end{array}$ & 2004 & $\begin{array}{l}\text { Drainage } \\
\text { fluid and } \\
\text { drain tip }\end{array}$ & $96 \mathrm{~h}$ & $\begin{array}{l}\text { Aerobic and anaerobic blood agar } \\
\text { plates } \\
\text { McConkey agar plate }\end{array}$ & Quantitative & Yes & $\begin{array}{l}5 \mathrm{~cm} \text { - aseptic } \\
\text { conditions }\end{array}$ & $\begin{array}{l}\text { Yes (povidone } \\
\text { iodine) }\end{array}$ \\
\hline $\begin{array}{l}\text { Takada et } \\
\text { al. }\end{array}$ & 2015 & Drain tip & Unspecified & Unspecified & Unspecified & Unspecified & $\begin{array}{l}2 \mathrm{~cm} \text { - aseptic } \\
\text { conditions }\end{array}$ & $\begin{array}{l}\text { Yes (povidone } \\
\text { iodine) }\end{array}$ \\
\hline Weinrauch & 2005 & Drain tip & 3 days & Blood agar plate & Qualitative & Unspecified & $\begin{array}{l}1 \mathrm{~cm} \text { - aseptic } \\
\text { conditions }\end{array}$ & Unspecified \\
\hline $\begin{array}{l}\text { Yamada et } \\
\text { al. } \\
\end{array}$ & 2016 & Drain tip & $48 \mathrm{~h}$ & $\begin{array}{l}\text { Aerobic and anaerobic blood agar } \\
\text { plates }\end{array}$ & Quantitative & Unspecified & $\begin{array}{l}1 \mathrm{~cm}-\text { aseptic } \\
\text { conditions }\end{array}$ & $\begin{array}{l}\text { Yes (povidone } \\
\text { iodine) }\end{array}$ \\
\hline $\begin{array}{l}\text { Zamora et } \\
\text { al. }\end{array}$ & 1999 & Drain tip & $48 \mathrm{~h}$ & Thioglycolate medium & Qualitative & Unspecified & $\begin{array}{l}1 \mathrm{~cm}-\text { aseptic } \\
\text { conditions }\end{array}$ & Unspecified \\
\hline
\end{tabular}


Table III. Quality of the included studies- A score of 1 is attributed if the answer is yes

\begin{tabular}{|c|c|c|c|c|c|c|c|c|c|c|}
\hline Study & Year & $\begin{array}{l}\text { Representativeness } \\
\text { of the exposed } \\
\text { cohort }\end{array}$ & $\begin{array}{l}\text { Selection } \\
\text { of the } \\
\text { non- } \\
\text { exposed } \\
\text { cohort }\end{array}$ & $\begin{array}{l}\text { Ascertainement } \\
\text { of } \\
\text { Exposure(result } \\
\text { of the culture) }\end{array}$ & $\begin{array}{l}\text { Demonstration } \\
\text { that outcome } \\
\text { was not present } \\
\text { at start }\end{array}$ & $\begin{array}{l}\text { Comparability: } \\
\text { confounders } \\
\text { adjusted for in } \\
\text { the analysis : } \\
\text {-age/sex (/1) } \\
\text { - additional } \\
\text { factors }(/ 1)\end{array}$ & $\begin{array}{l}\text { Assessement } \\
\text { of outcome }\end{array}$ & $\begin{array}{l}\text { Follow up } \\
\text { enough for } \\
\text { outcomes } \\
\text { to occur }\end{array}$ & $\begin{array}{l}\text { Adequacy } \\
\text { of follow } \\
\text { up }\end{array}$ & $\begin{array}{l}\text { Total } \\
\text { Score } \\
\text { (/9) }\end{array}$ \\
\hline Ahn & 2015 & 1 & 1 & 1 & 1 & 0 & 1 & 1 & 0 & 6 \\
\hline Aski & 2015 & 1 & 1 & 1 & 0 & 0 & 0 & 1 & 0 & 4 \\
\hline Becker & 1990 & 1 & 1 & 1 & 0 & 0 & 1 & 0 & 0 & 4 \\
\hline Becker & 1985 & 1 & 1 & 1 & 0 & 0 & 1 & 0 & 0 & 4 \\
\hline Bernard & 2002 & 1 & 1 & 1 & 0 & 0 & 0 & 1 & 0 & 4 \\
\hline Degnim & 2013 & 1 & 1 & 1 & 0 & 0 & 1 & 1 & 1 & 6 \\
\hline Girvent & 1994 & 1 & 1 & 1 & 0 & 0 & 1 & 0 & 0 & 4 \\
\hline Gunterberg & 1996 & 1 & 1 & 1 & 0 & 0 & 1 & 1 & 0 & 5 \\
\hline Krishnan & 2014 & 1 & 1 & 1 & 0 & 0 & 0 & 0 & 0 & 3 \\
\hline Lindahl & 1993 & 1 & 1 & 1 & 0 & 0 & 0 & 1 & 1 & 5 \\
\hline Overgaard & 1993 & 1 & 1 & 1 & 0 & 0 & 1 & 0 & 1 & 5 \\
\hline Petsatodis & 2009 & 1 & 1 & 1 & 1 & 0 & 1 & 1 & 1 & 7 \\
\hline Sankar & 2004 & 1 & 1 & 1 & 0 & 0 & 1 & 0 & 1 & 5 \\
\hline Takada & 2015 & 1 & 1 & 1 & 0 & 0 & 0 & 1 & 1 & 5 \\
\hline Weinrauch & 2005 & 1 & 1 & 1 & 0 & 0 & 0 & 1 & 1 & 5 \\
\hline Yamada & 2016 & 1 & 1 & 1 & 0 & 0 & 1 & 0 & 1 & 5 \\
\hline Zamora & 1999 & 1 & 1 & 1 & 0 & 0 & 1 & 0 & 0 & 4 \\
\hline
\end{tabular}




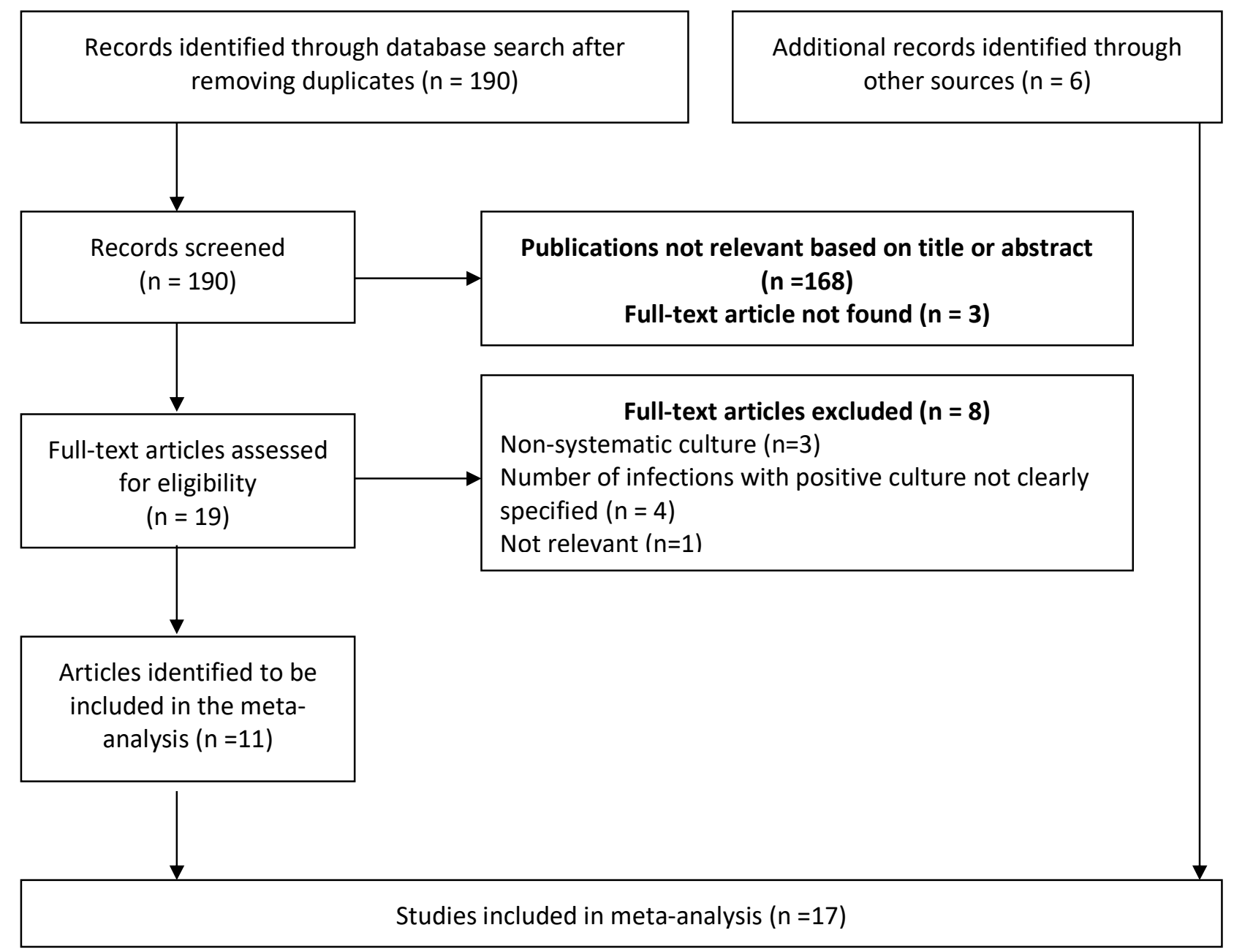


Toes

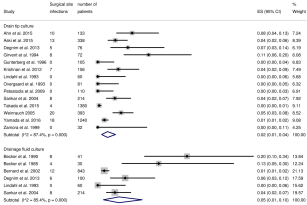




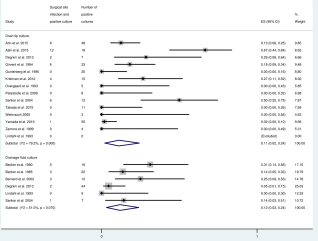




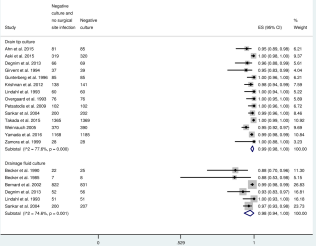


Funnel plot with pseudo 95\% confidence limits

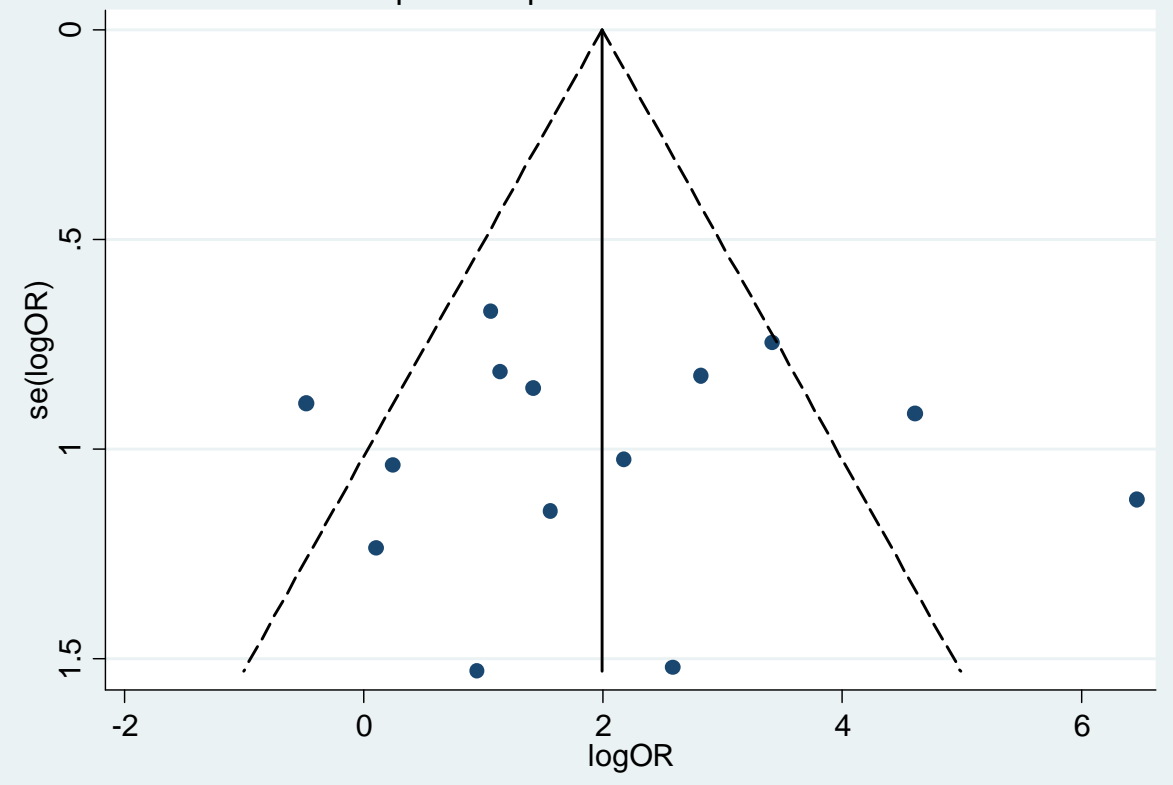

